\title{
DO CONDITIONALS HAVE TRUTH CONDITIONS?
}

DOROTHY EDGINGTON

Birkbeck College

University of London

\section{Introduction}

In the first part of this paper ( $\$ \oint 2$ and 4) I rule out the possibility of truth conditions for the indicative conditional 'If $A, B$ ' which are a truth function of $A$ and $B$. In the second part $(\$ 6)$ I rule out the possibility that such a conditional has truth conditions which are not a truth function of A and B; I rule out accounts which appeal, for example, to a stronger-than-truth-functional "connection" between antecedent and consequent, which may or may not be framed in terms of a relation between possible worlds, in stating what has to be the case for 'If $A, B$ ' to be true. I conclude, therefore, that the mistake philosophers have made, in trying to understand the conditional, is to assume that its function is to make a statement about how the world is (or how other possible worlds are related to it), true or false, as the case may be. Along the way ( $\$ \oint 3$ and 5) I develop a positive account of what it is to believe, or to be more or less confident, that if $\mathrm{A}, \mathrm{B}$, in terms of which an adequate logic of conditionals can be developed. The argument against truth conditions is independent of this positive account of the conditional, as I show that any truth-conditional account has counterintuitive consequences, as well as clashing with my positive thesis. But the positive account prevents the paper from merely having created a paradox, or a vacuum.

The paper is inspired by Ernest Adams' book, The Logic of Conditionals. ${ }^{1}$ My positive thesis is a less technical variant

1 Ernest Adams, The Logic of Conditionals (Reidel, 1975). Some historical background: Robert Stalnaker was, I believe, the first to suggest that insight 
of his. He proves the negative result too, but hardly perspicuously. My aim, in trying to extract an intuitively compelling argument from a somewhat baffling piece of algebra, is not only to make this way of thinking about conditionals more widely, and more deeply, appreciated. It is also, by weakening the assumptions, to provide a stronger proof of the negative result. I hope to render the positive thesis more plausible, too, by presenting it less technically.

It should not need emphasis that in the conditional we have an indispensible form of thought, which plays a large part in both theoretical reasoning about what is the case and practical reasoning about what to do. Its basic role may be described thus: We are not omniscient. We do not know as much as it would be useful for us to know. We are constantly faced with a range of epistemic possibilities - things that, as far as we know, may be true, when the question whether they are true is relevant to our concerns. As part or would be likely to be the case, given this supposition. The necessary to suppose (or assume) that some epistemic possibility is true, and to consider what else would be the case, or would be likely to be the case, given this supposition. The conditional expresses the outcome of such thought processes. It is worth remembering that any type of speech act can

into the semantics of conditionals might be gained from the probabilitytheorist's notion of a conditional probability, $\mathrm{P}(\mathrm{B} / \mathrm{A})$ (the probability of B given A). See his 'Probability and Conditionals', Philosophy of Science, 1970, reprinted in W. L. Harper, R. Stalnaker and G. Pearce (eds.), Ifs (Reidel, 1981). Judgements about how probable it is that if $A, B$, seem to coincide with judgements about the probability of $B$ given $A$. Stalnaker suggested that we should define the conditional as that proposition whose probability is so measured. David Lewis was the first to prove that there is no such proposition. See his 'Probabilities of Conditionals and Conditional Probabilities', Philo. sophical Review, 1976, reprinted in Harper, Stalnaker and Pearce (eds.), op. cit. As a result, Stalnaker and Lewis rejected the equation of the probability of a conditional with a conditional probability, the former defending a non-truth-functional account, the latter the truth-functional account of indicative conditional propositions. Adams, instead, retains the equation, and denies that the conditional is, strictly speaking, a proposition. In this paper, I support Adams. 
be performed within the scope of a supposition. There are conditional questions, comands, etc., as well as conditional assertions.

If he phones, what shall I say?

If I'm late, don't stay up.

If you're determined to do it, you ought to do it today.

To assert or believe 'If $A, B$ ' is to assert (believe) B within the scope of the supposition, or assumption, that A. This is bland enough, it would seem, to be not worth denying. Now, from a truth-conditional perspective, this double illocutionary force - an assumption, and an assertion within its scope - is eliminable -is reducible to, or equivalent to, a plain assertion. If conditionals have truth conditions, to assert 'If $\mathrm{A}, \mathrm{B}$ ' is to assert that its truth conditions obtain. One way of presenting the conclusion of this paper, then, is that the double illocutionary force is ineliminable; there is no proposition such that asserting it to be the case is equivalent to asserting that $B$ is the case given the supposition that $\mathrm{A}$ is the case. For any proposed truth condition, I shall show that there are epistemic situations in which there is a divergence between assent to the proposition with that truth condition and assent to the conditional.

The main argument of the paper concerns indicative conditionals. The thesis extends to subjunctive or counterfactual conditionals, but I shall not have space to argue that here. ${ }^{3}$ The distinction, from the present perspective, is not between

2 I take this formulation from J. L. Mackie, Truth, Probability and Paradox (Oxford, 1973), chapter 4. Mackie had the right idea, but did not have adequate arguments for his rejection of truth conditions.

3 See Ernest Adams, op. cit., chapter 4. More support for a unified theory of indicative and counterfactual conditionals is found in Brian Ellis, 'A Unified Theory of Conditionals', Journal of Philosophical Logic, 1978, and 'Two Theories of Indicative Conditionals', Australasian Joumal of Philosophy, 1984. 
two types of conditional connection, but between two types of supposition, or better, two kinds of context in which a supposition is made. One can suppose that $A$, taking oneself to know that not-A; and one can suppose that $A$, not taking oneself to know that not-A.

Typically, the subjunctive or counterfactual conditional is the result of the first kind of supposition, the open or indicative conditional the result of the second kind. An ap. parent difficulty which actually clarifies the point: I take myself to know that the carpet I am now looking at is not red. I may say "If it had been red, it would have matched the curtains." But I may also say "If it is red-well, I have gone colour-blind or am suffering some sort of delusion." In the subjunctive, I am taking it for granted that I am right in thinking it is not red. In the indicative, I am supposing that I am wrong. I am considering it to be an epistemic possibility that it is red, despite appearances. The importance of this for present purposes is that the positive account of indicative conditionals to follow assumes that the antecedent is always treated as epistemically possible by the speaker. When that condition is not satisfied, the conditional will be treated as a subjunctive, in the extension of the thesis. It will not matter if this distinction between two kinds of supposing does not match perfectly the grammatical distinction. It is enough if any conditional thought can be explained in one of the two envisaged ways.

One further remark about the methodology of this paper. While it is no part of my purpose to deny that some conditionals are certain, on $a$ priori or other grounds, the argument hinges upon the undeniable fact that many conditionals, like other propositions, are assented to or dissented from with a degree of confidence less than certainty. We are frequently

Ellis's own theory, though not truth-conditional, nevertheless falls foul of Lewis's negative result, despite his asertions to the contrary (as I shall argue in a sequel to this paper). 
uncertain whether if $A, B$, and our efforts to reduce our uncertainty often terminate, at best, in the judgement that it is probable (or improbable) that if A, B. Of course, the truthconditions theorist does not have to deny these undeniable facts. For him, to judge it more or less probable that if A, B is to judge it more or less probable that its truth conditions obtain. But this pinpoints his mistake. I show that uncertainty about a conditional is not uncertainty about the obtaining of any truth conditions. If a conditional had truth conditions, it would be. Therefore, a conditional does not have truth conditions. That is the structure of the argument to follow.

\section{The Truth-functional account}

There are sixteen possible truth-functions of A and B. Only one is a candidate for giving the truth conditions of 'If A, B'. Indeed, the following two assumptions are sufficient to prove that if 'If $\mathrm{A}, \mathrm{B}$ ' is truth-functional, it has the standard truth function (that is, it is equivalent to ' $\sim(\mathrm{A} \& \sim \mathrm{B})$ ' and to ' $\sim A \vee B$ '). (1) 'If $P \& Q$ then $P$ ' is true, whatever the truthvalues of $P$ and of $Q$; (2) Sentences of the form 'If $A, B$ ' are sometimes false, i.e., are not all tautologies. So we may safely speak of the truth-functional account.

It is important to recognise that there are powerful arguments in favour of the truth-functional account. Here are two: First, take any two propositions, B and C. Information that at least one of them is true seems sufficient for the conclusion that if $C$ is not true, $B$ is true. The converse inference is uncontroversial. Let $C$ be $\sim A$, and we appear to have vindicated the equivalence between ' $\sim A \vee B$ ' and 'If $A, B$ '. Second, information that $A$ and $C$ are not both true seems to license the inference that if $A$ is true, $C$ is not. Again, the converse implication is uncontroversial. Let $\mathrm{C}$ be $\sim B$, and we appear to have vindicated the equivalence between ' $\sim(A \& \sim B)$ ' and 'If $A, B$ '. (I shall show later that 
my positive account will preserve the force of these arguments, while no account in terms of non-truth-functional truth conditions can.)

But alas, there are well known difficulties for the truthfunctional account: $\sim \mathrm{A}$ entails $\sim(\mathrm{A} \& \sim \mathrm{B})$, for any $\mathrm{B}$. $B$ entails $\sim(A \& \sim B)$, for any $A$. So, according to his account,

The Labour Party will not win the next election

entails

If the Labour Party wins the next election, the National Health Service will be dismantled by the next government.

Anyone who accepts the former and rejects the latter is (on this account) inconsistent.

Similarly,

The Conservative Party will win the next election

entails

If a horrendous scandal emerges during the campaign, involving the Prime Minister and most of the Cabinet the Conservative Party will win the next election.

Again, anyone who accepts the former and rejects the latter has, on this account, inconsistent beliefs.

Grice argued ${ }^{4}$ that the truth-functional account can withstand these objections, provided that we are careful to distinguish the false from the misleading but true. There are many ways in which one can speak the truth yet mislead.

+ H. P. Grice, 'Logic and Conversation', in Donald Davidson and Gilbert Harman (eds), The Logic of Grammar (Encino, California: Dickenson Publishing Co., 1975). 
One way is to say something weaker than some other relevant thing one is in a position to say. Consider disjunctions. I am asked where John is. I firmly believe he is in the bar, and I know that he never goes near libraries. Inclined to be unhelpful but not wishing to lie, I say

$\mathrm{He}$ is either in the bar or in the library.

(I could go on: or at the opera or at church or...)

My hearer naturally concludes that this is the most precise information I am in a position to give, and also concludes form the truth (let us assume) that I told him

If he's not in the bar he is in the library.

The conditional, like the disjunction, according to Grice, is true provided that he's in the bar, but misleadingly asserted on these grounds.

I shall now show that this defense of the truth-functional account fails. Grice drew our attention to the existence of propositions which a person has grounds to believe true but which it would be unreasonable, in normal contexts, to assert. A contrast is invoked between what one may reasonably believe and what one may reasonably say, given one's grounds. I do not dispute that it is important to recognise this phenomenon. It does, I think, correctly explain the behaviour of disjunctions. Being sure that John is in the bar, I cannot consistently disbelieve the proposition ' $\mathrm{He}$ is either in the bar or in the library'; indeed, if I have any epistemic attitude to that proposition, it should be one of belief, however inappropiate it is for me to assert it.

A good enough test of whether the Gricean story fits the facts about disjunctions is this: I am asked to respond, 'Yes', 'No' or 'No opinion', to the disjunction. Being sure of one disjunct, I should surely answer 'Yes'. 
Here there is a striking contrast between disjunctions and conditionals. Imagine an opinion poll shortly before an election. Again, the subject is asked to respond 'Yes' if he thinks a proposition true, 'No' if he thinks it false, 'No opinion' otherwise. The subject is honest and prides himself on his consistency. Here are some of this responses:

1. The Labour Party will win (L) $\ldots \ldots \ldots \ldots$ No

2. The Labour Party won't win $(\sim \mathrm{L}) \ldots \ldots \ldots$ Yes

3. Either the Labour Party won't win or $-\left(\sim \mathrm{Lv} \_\right)$Yes

(Fill in the blank as you will: If he accepts that

(2) is true, he must, if rational, accept that at least one of two propositions, of which (2) is one, is true.)

4. If the Labour Party wins, the National Health Service will be dismantled by the next government (If $\mathrm{L}, \mathrm{N}$ )

No

Now, on the truth-functional account, this person has blatantly inconsistent beliefs. His saying ' $Y$ es' to (2) and 'No' to (4) is on a par with someone's saying 'Yes' to 'It's red and square' and 'No' to 'It's red'. The parallel is exact, for, on the truth-functional account, to deny (4) es equivalent to accepting $\mathrm{L} \& \sim \mathrm{N}$; he cannot consistently accept this yet deny L. But it is surely quite clear that our subject, in accepting (2) and rejecting (4), is not contradicting himself.

In the case of disjunctions, the predicted Gricean contrast between what it is reasonable to believe and what it is reasonable to say, given one's grounds, is discernible. In the case of conditionals, it is not. (I do not mean that the distinction does not apply to conditionals, but that it fails as a defense of the truth-functional account.) The purpose of the opinion poll is simply to elicit someone's opinions, irrespective of whether they would constitute appropiate 
remarks in an ordinary conversational interchange. We can stipulate that the subject is honest and serious. We must either accuse him of gross inconsistency, or accept that the conditional is not truth-functional.

This case against the truth-functional account cannot be made in terms of beliefs of which one is certain. Someone who is $100 \%$ certain that the Labour Party won't win has (on my account of the matter) no obvious use for an indicative conditional beginning 'If they win'. But someone who is, say, $90 \%$ certain that they won't win can have beliefs about what will be the case if they do. The truth-functional account has the immensely implausible consequence that such a person, if rational, is at least $90 \%$ certain of any conditional with that antecedent.

The principle I am appealing to is this:

If $\mathrm{A}$ entails $\mathrm{B}$, it is irrational to be more confident of $\mathrm{A}$ than of $\mathbf{B}$.

For instance, it is irrational to be more confident that a thing is red than that it is coloured. If the entailment is one-way, any way of rendering $A$ true renders $B$ true, but not conversely. $\mathrm{B}$ may be true when $\mathrm{A}$ is not. $\mathrm{B}$ has more chance of being true than $A .^{b}$

Given that some entailments are exceedingly complex, the principle, in its full generality, no doubt has the consequence that no one is fully rational. But here we are dealing with a simple, decidable, truth-functional entailment of the most basic kind. If the truth-functional account were correct, it would be a straightforward matter to get the subject to recognise that he has inconsistent beliefs.

- The principle is provable in probability theory. If $A$ entails $B, A \leftrightarrow A \& B$.

$\mathrm{B} \leftrightarrow(\mathrm{A} \& \mathrm{~B}) \vee(\sim \mathrm{A} \& \mathrm{~B}) . \mathrm{P}(\mathrm{B})=\mathrm{P}(\mathrm{A} \& \mathrm{~B})+\mathrm{P}(\sim \mathrm{A} \& \mathrm{~B}) \geqslant \mathrm{P}(\mathrm{A})$. 


\section{What it is to judge that if $A, B$}

The critique of the truth-functional account has yet to be completed, but it is useful here to introduce, by way of contrast, my positive account of the consistent judgements our subject is making when he accepts (2) and rejects (4). Here is a diagrammatic representation of how likely he considers the various possibilities, $L, \sim L, N, \sim N$, L\&N, $\mathrm{L} \& \sim \mathrm{N}$, etc. to be, vertical height representing probability:

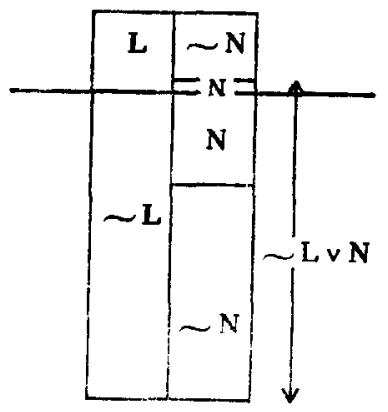

Fig. 1

In considering whether if $\mathrm{L}, \mathrm{N}$, the subject assumes $\mathrm{L}$; that is, he ignores the $\sim \mathrm{L}$-possibilities, the lower part of the diagram. Considering just those possibilities above the wide line, he asks how likely it is that $\mathrm{N}$. Answer: very unlikely. On the other hand, he is committed to believing $\mathrm{L} \supset \mathrm{N}$, that is $\sim \mathrm{L} \vee \mathrm{N}$, to be slightly more probable than $\sim \mathrm{L}$, that is, very likely.

To judge it probable that $A \supset B$ is to judge it improbable that $A \& \sim B$. To judge it probable that if $A, B$ is not only to judge it improbable that $A \& \sim B$, but to judge this to be less probable than A\&B. 'Is $B$ likely given $A$ ?' is the question 'Is A\&B nearly as likely as A?' 


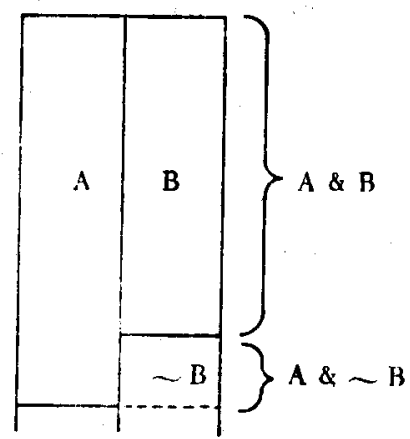

Fig. 2

That $A \& \sim B$ be small, which is necessary and sufficient for the conditional to be probable on the truth-functional account, is necessary but not sufficient on this account. If $A \& \sim B$ is large, greater than $1 / 2$, say, there isn't room for $A \& B$ to be larger still. However, $A \& \sim B$ can be small and $A \& B$ smaller still, as in the original example. In such a case, the material implication is probable but the conditional is not.

A simple example of the contrast between the two accounts: How likely is it that if this (fair) die lands an even number, it will land six? On my approach, we assume that the die lands an even number; given that assumption, there are three equal possibilities, one of which is six. So the answer is $1 / 3$. On the truth-functional approach, the answer is $2 / 3:$ If the die lands not-even or six, that is, if it lands, $1,3,5$ or 6 , the conditional is true. So the conditional has four chances out of six of being true.

4. The case against truth-functionality continued

Let us continue our questionnaire to consider the second paradox of material implication: 
5. The Conservative Party will win (C) ...... Yes

6. Either _ or the Conservative Party will win (-vC) (Fill in the blank as you like.) ...... Yes

7. If a horrendous scandal emerges involving the Prime Minister and most of the Cabinet, the Conservative Party will win (If $S, C$ ) $\ldots \ldots \ldots$ No

Such answers are not inconsistent. I grant that someone who is $100 \%$ certain that the Conservatives will win will accept any conditional with an antecedent which he takes as an epistemic possibility and $C$ as consequent. But that is not enough to prove the validity of the inference from $\mathrm{C}$ to If $\mathrm{S}, \mathrm{C}$. Suppose our subject is $90 \%$ certain that the Conservatives will win. He allows that they may not win, and that if certain, in his view unlikely, things happen, they will not win. So it is consistent to have a high degree of confidence that $\mathrm{C}$ and a low degree of confidence that if $\mathrm{S}, \mathrm{C}$. On the truth-functional account, this is, again, logically on a par with being very confident that it's red and square but very unconfident that it's square.

On the other hand, his high degree of confidence in (5) does constrain him to at least that degree of confidence in (6).

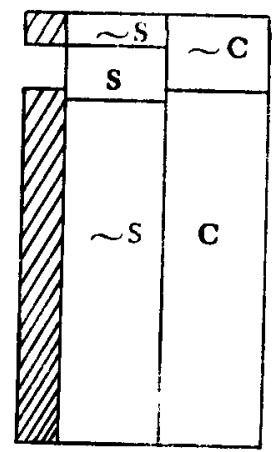

D $\sim \mathrm{s} \vee \mathrm{C}$

Fig. 3 
I said that the Gricean defence depends on a contrast between when a conditional is fit to be believed and when it is fit to be asserted. I have shown that the conditions under which a conditional is believed do not fit the truth-functional account. So this defence fails. Frank Jackson defends the truth-functional account differently. ${ }^{\circ}$ His thesis is that for a conditional to be assertible, it must not only be believed that its truth conditions are satisfied, but the belief must be robust or resilient with respect to the antecedent. This means that one would not abandon belief in the conditional if one were to discover the antecedent to be true. This ensures that an assertible conditional is fit for modus ponens. This condition is not satisfied if one believes $\mathrm{A} \supset \mathrm{B}$ solely on the grounds that $\sim A$. If one discovered that $A$, one would abandon one's belief that $A \supset B$, rather than conclude that $B$. I think this defence is open to the same objections as Grice's. There is simply no evidence that one believes a conditional whenever one believes the corresponding material implication, and then is prepared to assert it only if some further condition is satisfied.

I have been assuming that if a sentence is correctly assigned certain truth conditions, a competent speaker believes that sentence if and only if he believes these conditions are fulfilled; and, provided that he is honest and has no wish to hide his opinion, will say so if asked 'Do you believe that A?' It may be objected that the distinction between its truth conditions and other aspects of a sentence's use is more a theorist's, less a practitioner's distinction than I have allowed. If this is so, then we must ask, what theoretical purpose is served by the assignment of these truth conditions? To explain the validity of inferences? But it does this very badly. I have shown this for the two simplest

6 Frank Jackson, 'On Assertion and Indicative Conditionals', Philosophical Review, 1979, and 'Conditionals and Possibilia', Proceedings of the Aristotelian Society, 1980-1981. 
types of example, but these generate indefinitely many other counterintuitive "valid" inferences. Here is a new "proof" of the existence of God:" "If God does not exist, then it is not the case that if I pray my prayers will be answered (by Him). I do not pray. (So it is the case that if I pray...) So God exists." The extent to which the truth-functional account succeeds in capturing the validity of inferences is explained by the fact that the material implication is essentially weaker than the indicative conditional (see above) and so is the extent to which it fails.

Another suggestion is that the truth functional account explains the behaviour of embedded conditionals: It explains the contribution of the truth conditions of 'If $A, B$ ' to those of '(If $A, B$ ) or (if C, D)', for example. But, unsurprisingly, the truth-functional account yields counterintuitive results for sentences containing conditionals as constituents. For example, it tells us that the following is a tautology:

(If $A, B$ ) or (if not-A, B)

So anyone who rejects the first conditional must, on pain of contradiction, accept the second. So if I reject the conditional 'If the Conservatives lose, Thatcher will resign', I am committed to accepting 'If the Conservatives win, Thatcher will resign'! ${ }^{8}$

We have not been able to find any theoretical purpose well served by these truth conditions. There does not appear to be any indirect evidence in its favour to mitigate against the direct evidence against it -the fact that belief in a conditional and belief in a material implication do not coincide.

7 I owe this example to W. D. Hart.

8 David Lewis, in 'Probabilities of Conditionals and Conditional Probabilities', $o p$. cit., gives as his reason for rejecting the no-truth-conditions view that it cannot explain embedded conditionals. ( $/ f$ s, op. cit., p. 136.) He roes on to defend the truth-functional account, attempting to explain away some of its paradoxical features. But he does not address the problem that the truthfunctional account gives absurd results for embedded conditionals. 


\section{The positive account continued}

I outlined my positive account of belief in a conditional in $\S 3$. In considering how likely it is that if $\mathrm{A}, \mathrm{B}$, one assumes $\mathrm{A}$, that is, ignores the possibility that $\sim \mathrm{A}$. Relative to that assumption, one considers how likely it is that $\mathrm{B}$. (See fig. 2.) This yields the following criterion:

$\mathrm{X}$ believes that (judges it likely that) if $\mathrm{A}, \mathrm{B}$, to the extent that he judges that $A \& B$ is nearly as likely as $A$

or, roughly equivalently, to the extent that he judges $A \& B$ to be more likely than $A \&-B$.

If we were to make the idealising assumption that a person's subjective probability judgements are precise enough to be assigned numbers between one and zero inclusive, we could be more precise and say that the measure of X's degree of confidence in the conditional 'If $\mathrm{A}, \mathrm{B}$ ' is the ratio

$$
\frac{P_{x}(A \& B)}{P_{x}(A)}
$$

This ratio is known in probability theory as the conditional probability of $B$ given $A$. Our positive thesis could be stated, then

A person's degree of confidence in a conditional, if $A, B$, is the conditional probability he assigns to $B$ given $A$.

However, my argument does not depend upon the idealising assumption of precise numerical values. Also, even if we grant numerical values, the ratio must not be taken as a reductive definition of the conditional probability, as though one first had to ascertain how probable it is that $A$ and that $\mathrm{A} \& \mathrm{~B}$, and then divide the second by the first. Typically, one does not have to decide how likely it is that $A$ in order 
to judge that $B$ is likely given A. I may have given no thought to the matter of how likely it is that the Labour Party will win yet be confident that if they win public spending will increase; this latter confidence entails confidence that, however likely it is that they win, it is nearly as likely that (they win and public spending increase). The non-reducibility is particularly obvious when, as part of some practical reasoning, one considers conditionals of the form 'If I do $x$, such-and-such will happen'. It would be absurd to hold that I have to know how likely it is that I will do $\mathrm{x}$ before I can assess such a conditional.

Let us consider some special cases. If I am certain of a conditional, for example that if he is a bachelor, he is unmarried, then, however likely it is that he is a bachelor, it is equally likely that he is a bachelor and unmarried. The ratio is 1 . A conditional in which $I$ have the lowest possible degree of confidence, for example, that if he's a bachelor, he's married, I assign probability 0 to the conjunction of antecedent and consequent, and hence to the ratio. If I think it is 50-50 that if you toss this coin, it will land heads, then, whatever the probability that you toss it, the probability that (you toss it and it lands heads) is half as much: the ratio is $1 / 2$.

This measure has the advantage of allowing the probability of the conditional to be independent of the probability of the antecedent. On the truth-functional account, the probability that if you toss the coin it lands heads depends crucially on how probable it is that you toss it. Suppose it is much less likely now that you toss the coin than it was a minute ago. The probability of the material implication, which is equivalent to:

Fither you won't toss it, or (you will and it will land heads)

has greatly increased. But the probability of the consequent 
on the assumption that the antecedent is true has remained the same.

Non-truth-functional accounts of the truth conditions of conditionals demand some sort of "strong connection" between antecedent and consequent for the conditional to be true. Such a connection is clearly lacking in

If you toss this (fair) coin, it will land heads.

On such accounts, the conditional is then certainly false. It should have probability 0 . But surely, if someone is told "the probability is 0 that if you toss it it will land heads", he will think it is a double-tailed or otherwise peculiar coin. Keeping the structure but changing the content of the example - a dog either bites or cowers when strangers approach, apparently at random, and with about equal frequency of each. Could one in good faith tell a stranger that the probability is zero that if he approaches, the dog will bite?

I think I have said enough to render plausible the claim that the measure of acceptability of a conditional 'If A, B' is the conditional probability of $B$ given $A$. Without idealising, the basic thesis is that to assess how probable it is that if $\mathrm{A}, \mathrm{B}$, one assumes $\mathrm{A}$, and considers how probable it is that $B$, under that assumption; and that that thought process is equivalent to considering whether $\mathrm{A} \& \mathrm{~B}$ is nearly as likely as $A$. More evidence for the thesis comes from considering which inference-patterns involving conditionals are valid. There is not space to present this evidence fully, ${ }^{9}$ but I shall end this section by saying something about the inference from ' $A \vee B$ ' to 'If not-A, B'. As I said at the beginning of section 2 , if this inference were valid, the truthfunctional account would be correct. And the inference appears very plausible. We shall see how to explain these facts.

- See Ernest Adams, op. cit., chapter 1. 
If I am agnostic about $\mathrm{A}$, and agnostic about $\mathrm{B}$, but confident that $A$ or $B, I$ must believe that if not-A, $B$.

This is the normal situation in which a belief that $A$ or $B$ will play an active role in my mind, as a premiss or as anything else; for example, someone has teld me that $A$ or $B$, or I have eliminated all but these two possibilities.

On the other hand, if my belief that $A$ or Be derives solely from my belief that $A$, the inference is not justified. For example, I wake up and look at the clock. It says eight

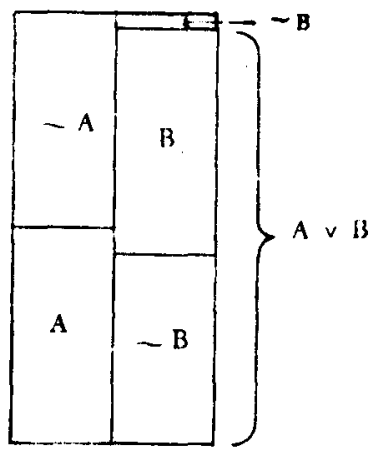

Fig. 4

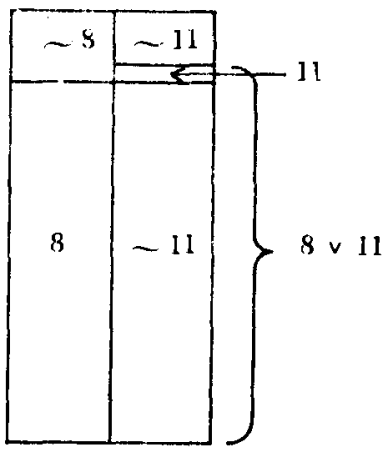

Fig. 5 
o'clock. It is fairly reliable but by no means infallible. I am 90\% confident that it is eight o'clock (within whatever degree of precision with which we make such statements). So, were I to consider the matter, I must be at least $90 \%$ confident that it is either eight o'clock or eleven o'clock. But this gives me no grounds for confidence that if it is not eight, it is eleven.

As it is rare and rather pointless to consider disjunctions in circumstances such as these, it is not surprising that we mistake 'A or B; therefore, if not-A, B' for a valid argument.

6. The case againts non-truth-functional truth conditions

If a conditional has truth conditions, the probability of a conditional is the probability that those conditions obtain. Suppose that a conditional has truth conditions which are not a truth-function of its antecedent and consequent. This means that the number of logically possible combinations of truth-values of $\mathrm{A}, \mathrm{B}$, If $\mathrm{A}, \mathrm{B}$ is between five and eight. That is, at least one and at most all four possible combinations of truth-values for $A$ and $B$ split(s) into two possibilities: 'If $A, B$ ' true; 'If $A, B$ ' false. At most three of the following eight combinations of truth-value can be ruled out $a$ priori:

\section{A B If A, B}

$\begin{array}{cccc}1 \mathrm{a} & \mathrm{T} & \mathrm{T} & \mathrm{T} \\ 1 \mathrm{~b} & \mathrm{~T} & \mathrm{~T} & \mathrm{~F} \\ 2 \mathrm{a} & \mathrm{T} & \mathrm{F} & \mathrm{T} \\ 2 \mathrm{~b} & \mathrm{~T} & \mathrm{~F} & \mathrm{~F} \\ 3 \mathrm{a} & \mathrm{F} & \mathrm{T} & \mathrm{T} \\ 3 \mathrm{~b} & \mathrm{~F} & \mathrm{~T} & \mathrm{~F} \\ 4 \mathrm{a} & \mathrm{F} & \mathrm{F} & \mathrm{T} \\ 4 \mathrm{~b} & \mathrm{~F} & \mathrm{~F} & \mathrm{~F}\end{array}$


I shall now show that wherever truth-functionality fails, there are consequences incompatible with the positive thesis about the acceptance of a conditional; and that where there is a clash, intuition continues to favour the positive thesis rather than the non-truth-functional truth conditions thesis.

First, suppose

Assumption 1: A conditional has truth conditions which are not truth-functional when ' $A$ ' and ' $B$ ' are both true.

Thus $l a$ and $l b$ are two distinct possibilities. On this assumption, 'If A, B' would be like 'A before B' and 'A because B'. For example, the truth of 'John went to Paris' and of 'Mary went to Paris' leaves open the question whether 'John went to Paris before Mary went to Paris' is true; its truth depends on more than the truth values of its constituents.

Consequence of assumption 1:

$\mathrm{C}_{1}$ : Someone may be sure that $\mathrm{A}$ is true and sure that $\mathrm{B}$ is true, yet not have enough information to decide whether 'If $A, B$ ' is true; one may consistently be agnostic about the conditional while being sure that its components are true (as for 'A before B').

This consequence is central to my argument. I pause to clarify and defend it. It does not quite follow merely from the assumption of non-truth-functionality. There are exceptions to claims of the same form. But the exceptions are special cases, which do not cast doubt on the case of conditionals.

First exception: Take the operator 'It is self-evident that...' 'It is self-evident that $A^{\prime}$ ' is not a truth-function of $A$ when $A$ is true. But it does not follow that one may be sure that $A$ yet agnostic about whether it is self-evident that A. For there is no room for uncertainty about propositions 
of this last form. However, such an operator clearly contrasts with the operators, 'If', 'before' 'because', which, in general, make contingent claims, about which there is plenty of room for uncertainty. Of course there are self-evident conditionals, such as 'If he's a bachelor, he's unmarried'; but they owe their self-evidence to the particular contents of the constituent propositions. They are not self-evident just because of the meaning of 'if'.

It could be objected that my argument, resting on $\mathrm{C}_{1}$, will not have shown that those conditionals which are self-evident don't have truth-conditions. But this would be to claim that 'if' is ambiguous: that it has a different meaning in 'If he's a bachelor he's unmarried' and 'If John is in Paris, so is Mary'. I see no grounds for an ambiguity. My positive thesis has the consequence that self-evident conditionals are certain -the consequent is certain on the supposition that the antecedent is true; and that conditionals about which one may be uncertain cannot be understood in terms of truth conditions. It offers a unified account of indicative conditionals which is incompatible with a unified account in terms of truth conditions. Unified accounts are prima facie preferable to accounts which postulate ambiguities. In the absence of a strong case for ambiguity, then, my argument still applies to all conditionals.

A second counterexample to the general claim about nontruth-functionality I owe to Raúl Orayen: Interpret ' $A * B$ ' as ' $I$ am sure that $A$ and sure that $B$ '. This is not a truth function of $A$ and $B$ when $A$ and $B$ are both true. But it does not follow that $I$ can be sure that $A$ and sure that $B$ yet agnostic about $A^{*} B$. It could be replied that, as we do not have incorrigible access to our own beliefs, it is possible to be sure that $A$, sure that $B$, yet unsure about whether one is sure, i.e., unsure about $A * B{ }^{* 0}$ But in any case, any putative truth conditions of 'If $A, B$ ' will surely be unlike

10 I owe this point to Raymundo Morado. 
those of ' $A * B$ ' in being independent of the state of mind of any one individual. The hypothesis under consideration, Assumption 1, is that the truth of $A$ and of $B$ is insufficient to determine the truth of 'If $A, B$ '. One doesn't have to be an extreme realist about truth to insist that whatever else is necessary is in general nothing to do with one individual's epistemic state. I say "in general" because, as before, there will be special cases - conditionals which are about the state of mind of some one individual; and perhaps to some of these, the individual concerned has incorrigible access. But, to repeat, we are in the business of interpreting 'If' for all conditionals. The contribution it makes to the (alleged) truth conditions of sentences in which it occurs makes no reference to my state of mind- though in special cases, the ' $A$ ' or the ' $B$ ' in 'If $A, B$ ' may do so.

$C_{1}$ still stands, then. Now $C_{1}$ is incompatible with our positive account. Being certain that $A$ and that $B$, a person must think $A \& B$ is just as likely as $A$. $H e$ is certain that $B$ on the assumption that $A$ is true.

$\mathrm{C}_{1}$ also conflicts with common sense. Admittedly, the conditional 'If $\mathrm{A}, \mathrm{B}$ ' is not of much interest to someone who is sure that both ' $A$ ' and ' $B$ ' are true. But he can hardly doubt or deny that if $\mathrm{A}, \mathrm{B}$, in this epistemic state.

Establishing that the antecedent and consequent are true is surely one incontrovertible way of verifying a conditional.

Assumption 1 must, then, be rejected. Truth-functionality cannot fail when ' $A$ ' and ' $B$ ' are both true. 'A\&B' is sufficient for 'If $A, B$ '. Putative possibility $l b$ does not exist. We proceed to the second stage of the argument.

Assumption 2: A conditional has truth conditions which are not truth-functional when ' $A$ ' is true and ' $B$ ' is false.

Consequence of assumption 2:

$C_{2}$ : Someone may be sure that ' $A$ ' is true and sure that ' $B$ ' is 
false yet not have enough information to settle whether 'If $A, B$ ' is true, and hence be agnostic about the latter.

As with $\mathrm{C}_{1}$, this is incompatible with our positive account, and also with common sense. Such a person knows enough to reject the claim that ' $B$ ' is true on the assumption that $A$. ' $A \& \sim B$ ' is sufficient to refute 'If $A, B$ '. Assumption 2 is false. Putative possibility $2 \mathrm{a}$ does not exist.

We have shown, then, that if a conditional has truth conditions, they are truth-functional for the two cases in which ' $\mathrm{A}$ ' is true. We shall now consider the cases in which ' $\mathrm{A}$ ' is false.

Assumption 3: A conditional has truth conditions which are not truth-functional when ' $A$ ' is false and ' $B$ ' is true.

Now suppose someone is sure that B but is uncertain whether A. On our positive account, he knows enough to be sure that if $A, B$ : If $B$ is certain, $A \& B$ is just as probable as $\mathrm{A}$. This also accords with common sense. But according to assumption 3 , there are three possibilities - three ways the world may be- compatible with his knowledge:

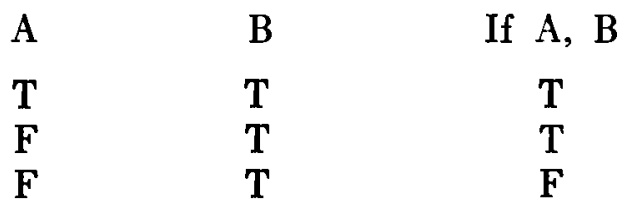

(I rely on the fact that we have established truth-functionality for the top line.)

' $A$ ' may be false, and if it is, some further condition has to be satisfied for 'If $A, B$ ' to be true, and he may not know whether it is satisfied. According to Stalnaker, ${ }^{11}$ for

11 Robert Stalnaker, 'A Theory of Conditionals', in Studies in Logical Theory, American Philosophical Quarterly, Monograph No. 2 (Blackwell, 1968), reprinted in E. Sosa (ed.), Causation and Conditionals (Oxford, 1975) and in Ifs, op. cit. 
instance, the further condition is that ' $\mathrm{B}$ ' be true in the closest possible world to the actual world in which ' $A$ ' is true. And he might not know enough about the actual world to know whether this is so.

An example might help. I complain to Joln that he has not replied to my letter. He says he did - he posted the reply some weeks ago. I am not sure whether to believe him. Let ' $A$ ' be 'He posted the reply' and ' $B$ ' be 'I didn't receive it'. Our positive account has it that $B$ is certain on the assumption that $A$, and so does common sense. But by assumption 3, I should reason like this: "I didn't receive the letter. Suppose he posted it: Then the conditional is true. But suppose he didn't post it: This, together with the fact that I didn't receive it, is not sufficient for the conditional. It depends (say) on whether in the closest possible world in which he did post it, I still didn't receive it. And I can't be sure of that."

Assumption 3, then, is incompatible with our positive account, and once more, intuition vindicates our account. Assumption 3 must be rejected. Putative possibility $3 \mathrm{~b}$ does no exist.

Finally, Assumption 4: Truth-funtionality fails when ' $A$ ' and ' $B$ ' are both false.

Now consider someone who is sure that ' $A$ ' and ' $B$ ' have the same truth-value, but is uncertain which. For example he knows that John and Mary spent yesterday evening together, but doesn't know whether they went to the party. According to our positive account and according to common sense, he knows enough to be sure that if John went to the party $(\mathrm{J})$, Mary did (M). (J\&M is as likely as $J ; M$ is certain on the assumption that J.) But according to assumption 4, he has to consider three possibilities compatible with his knowledge: 


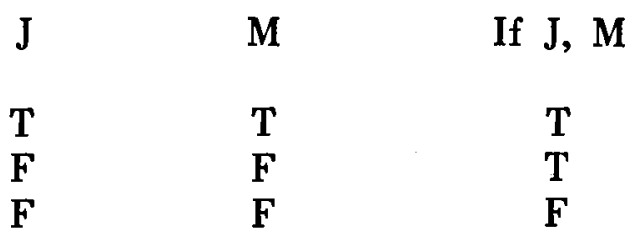

$\mathrm{J}$ and $\mathrm{M}$ may both be false, and if they are, some further condition has to be satisfied for 'If $\mathrm{J}, \mathrm{M}$ ' to be true. Perhaps the further question, if John and Mary didn't go, is whether Mary would have gone if John had, and he can't be certain of that. Our positive account and Assumption 4 diverge, and intuition, once more, favours our account.

Assumption 4 must be rejected. Putative possibility $4 \mathrm{~b}$ does not exist.

We have reached the end of our proof. That the conditional has non-truth-functional truth conditions entails that at least one of Assumptions 1 to 4 is true. But whichever we accept, we can find conditionals whose acceptability (or unacceptability), both intuitively and in terms of our positive account, conflicts with that assumption.

Given truth conditions, we have a paradox. It is no accident that, given truth conditions, there is philosophical disagreement about whether or not they are truth-functional. For there are aceptable conditionals whose acceptability cannot be accomodated by any non-truth-functional account. I have used some of these in the above proof. And there are unacceptable conditionals whose unacceptability cannot be accomodated by the truth-functional account. I used these earlier in the case against truth-functionality. But our positive account resolves this paradox. The mistake is to think of conditionals as part of fact-stating discourse.

Perhaps we can get closer to the heart of the paradox with the following case. I am wondering whether A and whether B. Someone comes along who knows their truthvalues, but feels unable to tell me all he knows. He says 
'The most I am able to tell you is this: $\sim(A \& \sim B)$.' This is enough for me to conclude that if $A, B$. Now, $(A \& \sim B)$ does not entail 'If A, B'. That is the truth-functional account, with all its difficulties. But belief that $\sim(\mathrm{A} \& \sim \mathrm{B})$ in the $a b$ sence of belief that $\sim \mathrm{A}$ is sufficient for belief that if $A, B$.

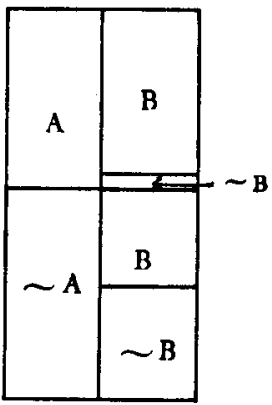

Fig: 6

No non-truth-functional account can accommodate that fact.

7. Some concluding observations

The argument makes no assumptions about what truth consists in - beyond the fact that one can be uncertain whether a sentence has this property, and judge it likely or unlikely that it does. Whatever 'true' means, to judge it likely that it applies to $B$ on the assumption that it applies to $A$ is not equivalent to judging it likely that it applies to something else. The linguistic or mental act of supposing is ineliminable from conditionals, and they cannot be reduced to straight assertions or beliefs.

Another way of putting the conclusion is this. One can be certain or uncertain about a proposition, A. Uncertainty 
about $A(\sim A, A v B$, etc.) has a structure which is not only compatible with the proposition's having one or other truth value, but requires that it does. One can be certain or uncertain about whether if $A, B$. Uncertainty about a conditional has a structure which does not require that the conditional has one or other truth-value; moreover, it is incompatible with this.

There are several reasons why this argument is important. This is the most general one: A hard argument against (or for) the applicability of the concept of truth to a given area of discourse is a rare thing. It is just possible that this one may shed light on controversies about the applicability of the concept in other areas. Given certain key features of the epistemology of discourse of the kind in question, we can ask, does this epistemology fit with even a minimum metaphysics of truth?

Another reason why the consequences of the argument are far-reaching is that it has become increasingly fashionable to 'analyse' other important philosophical concepts in terms of conditionals, for example, causation, natural laws, dispositional properties, and more recently, knowledge. The standard account of statements of the form 'All A's are B' is also a striking example. There is much that needs to be re-examined in the light of this thesis.

Perhaps most importantly, the criterion for the validity of deductive arguments needs to be restated in the light of this thesis. The standard criterion is that valid arguments preserve truth. But such arguments contain conditionals, and according to the thesis $I$ have defended, conditionals are not suitable candidates for truth. Now, our interest in the validity of arguments is epistemological. A valid argument is one such it is irrational to accept the premisses and reject the conclusion. Given our account of the acceptance-condition of the conditional, this epistemic criterion can be preserved, and extended. An argument is valid if and only if 
it is inconsistent to judge each premiss highly probable and the conclusion highly improbable. Adams has made this criterion precise. ${ }^{12}$ It explains why certain patterns of inference involving conditionals are valid; and it isolates the unusual conditions under which others, which appear valid, fail. I discussed one such example at the end of $\$ 5$.

Finally, this argument should not be construed as part of a general attack on truth-conditional semantics. It depends on a contrast between the roles of the constituent sentences of a conditional and the conditional itself. It does not require, but fits well with a truth-conditional account of our understanding of the former.

Indeed, this anti-realist argument about conditionals is more puzzling for a general anti-realist than for a philosopher with strong realist tendencies. For the latter, let us say, a declarative sentence identifies a possible state of affairs. It is true if and only if the state of affairs identified obtains. For him, the argument shows that there are no conditional states of affairs. For an anti-realist who construes truth along the lines of what is ideally rationally acceptable, it is much more puzzling that the notion cannot be applied to conditionals. But, as I said before, the argument itself makes no assumptions about the nature of truth.*

12 See Ernest Adams, op. cit., chapters 1 and 2.

* Earlier versions of this paper were read to the Oxford Philosophical Society in 1984 and the Conference on the Philosophy of Logic and Language in Leicester, 1985. It formed part of the material of a lecture course on Conditionals given in the Instituto de Investigaciones Filosóficas, Universidad Nacional Autónoma de México in the summer of 1985. I am grateful to these audiences and many other people for useful comments, and especially, to Raúl Orayen for his enthusiasm and constructive criticism. 


\section{RESUMEN 1}

\section{Introducción}

En el trabajo se prueba que el condicional indicativo de la forma 'Si A,B' no tiene condiciones de verdad. En las secciones 2 y 4 se elimina la posibilidad de condiciones de verdad veritativo-funcionales y en 6 la de condiciones de verdad no veritativo-funcionales. $\mathrm{El}$ error principal cometido por los filósofos al analizar los condicionales habría sido, pues, el de suponer que son afirmaciones verdaderas o falsas acerca del mundo (o de mundos posibles conectados con el real). En las secciones 3 y 5 se desarrolla también una teoría positiva alternativa acerca de qué es creer en un condicional (aunque cl argumento contra la doctrina de condiciones de verdad puede desarrollarse con independencia de tal teoría positiva). En la sección 7 se hacen algunas precisiones finales sobre los argumentos y tesis desarrollados.

El artículo se inspira en el libro The Logic of Conditionals, de Ernest Adams. La teoría positiva defendida es una variante del enfoque de ese libro; los argumentos en contra de las condiciones de verdad son distintos y se proponen con la doble finalidad de hacer más clara la argumentación y reforzarla, mediante el uso de supuestos más débiles.

En nuestros razonamientos teóricos y prácticos tenemos en cuenta a veces posibilidades epistémicas (cosas que pueden ser verdaderas, hasta donde sabemos, aunque quizás no tenemos seguridad de ello). A menudo suponemos que una de esas posibilidades es verdadera y consideramos que ocurriria, o que sería probable que ocurriese, dado ese supuesto. El condicional expresa el resultado de tal proceso de pensamiento. Afirmar (o creer) ' $\mathrm{Si} A, \mathrm{~B}$ ' es afirmar (o creer) B, dentro del ámbito de la suposición de que $\mathrm{A}$. Si los condicionales tuvieran condiciones de verdad, dado un condicional ' $\mathrm{Si} A, B$ ', afirmarlo equivaldría a afirmar una proposición, que a su vez afirmaría que las condiciones de verdad de ' $\mathrm{Si} A, B$ ' se cumplen. La prueba de la autora demuestra que tal proposición no existe.

El argumento principal del artículo se ocupa de condicionales indicativos; puede extenderse también a condicionales subjuntivos o contrafácticos, aunque por razones de espacio no se hace en este

1 Resumen de Raúl Orayen. 
trabajo. Según el enfoque de la autora, la diferencia entre los condicionales de uno y otro tipo radica en una diferencia entre los contextos en que se hace la suposición de que $A$, cuando se afirma o cree que $B$, dado A. La autora supone en el trabajo que, en el caso de los condicionales indicativos, el antecedente siempre se trata como epistémicamente posible para el hablante. El argumento a desarrollar se apoya también en el hecho obvio de que muchos condicionales se afirman o niegan con un grado de confianza menor que la certeza. La autora tratará de establecer su tesis mostrando que la incertidumbre acerca de un condicional no se puede identificar con la incertidumbre sobre el cumplimiento de un conjunto de condiciones de verdad, sea cual sea la elección de tal conjunto.

\section{El análisis veritativa-funcional}

Supuestos obvios conducen a la conclusión de que si ' $\mathrm{Si} A, B$ ' tiene condiciones de verdad veritativo-funcionales, tiene la tabla de verdad usual, según la cual es equivalente a '-( $A$ \& -B)' y a '-A $\vee$ B'; para eliminar las condiciones de verdad veritativo-funcionales, basta eliminar, pues, el análisis basado en la tabla usual.

Hay argumentos importantes en favor del análisis veritativofuncional usual. Por ejemplo, de la información de que por lo menos una de las dos proposiciones $\mathrm{B}, \mathrm{C}$, es verdadera, parece deducirse que si $\mathrm{C}$ no es verdadera, $\mathrm{B}$ lo es. La implicación conversa está fuera de controversia. Si tomamos $C=-A$, quedaría probado entonces que ' $-\mathrm{A} \vee \mathrm{B}$ ' equivale lógicamente a ' $\mathrm{Si} \mathrm{A}, \mathrm{B}$ '. Un argumento similar probaría la equivalencia entre '-(A \& -B)' y 'Si A,B'. (Aunque se rechazan en el trabajo las conclusiones sobre condiciones de verdad del condicional que se siguen de estas inferencias, la teoría positiva de la autora puede dar una explicación de la fuerte plausibilidad de los argumentos citados.)

Pero el análisis veritativo-funcional lleva a dificultades graves. Se puede probar en la teoría de la probabilidad que si A implica lógicamente $B$, la probabilidad de $B$ no puede ser menor que la de A, es decir:

(1) Si $A$ implica lógicamente $B$, entonces $P(A) \leq P(B)$.

Debido a este teorema, podría esperarse que si A implica $B$ y tal implicación no es extraordinariamente compleja, un individuo racional no puede creer fuertemente en $A$ y no creer (o tener una creencia mucho más débil) en $B$. Pero la autora muestra que ése 
es precisamente el caso, en algunos ejemplos, si el análisis veritativofuncional es verdadero. Sean $A$ y $B$ las proposiciones siguientes:

(A) El Partido Laborista no ganará la siguiente elección.

(B) Si el Partido Laborista gana la siguiente elección, el Sistema Nacional de Salud será desmantelado por el siguiente gobierno.

De acuerdo con el análisis veritativo-funcional, A implica B. Por (1) se seguiría que es irracional tener una creencia más fuerte en $A$ que en B. Sin embargo, parece perfectamente obvio que una persona racional puede creer en $\mathrm{A}$ y no en $\mathrm{B} .^{2}$

Grice ha tratado de solucionar las paradojas usuales del análisis veritativo-funcional del condicional distinguiendo entre lo que es falso y lo que es contextualmente engañoso. Supongamos, por ejemplo, que yo creo fuertemente que Juan está en el bar y sé que nunca anda cerca de una biblioteca. $\mathrm{Si}$ alguien me pregunta dónde está Juan y yo respondo:

(2) Él está en el bar o en la biblioteca, el interlocutor puede concluir que

(3) Si él no está en el bar, está en la biblioteca.

Grice sostiene que en un caso como éste, si realmente Juan está en el bar, (2) es verdadero, y sin embargo su afirmación en el contexto imaginado sería engañosa para el interlocutor, que pensaría que (2) es la afirmación más precisa que yo puedo hacer en las circunstancias. Esto muestra una diferencia entre lo que es razonable creer y lo que es razonable afirmar en un contexto normal (si uno es honesto y no pretende confundir al interlocutor con la afirmación). Aunque (2) es verdadero en la situación imaginada, no es apropiado usarlo como respuesta a la pregunta sobre Juan en el contexto ilustrado; es razonable creer que es verdadero, pero no es razonable afirmarlo, puede resultar engañoso.

Grice trata (3) de la misma manera que a (2). Pero la autora considera que si bien el análisis es adecuado para la disyunción, no lo es para el condicional. Un test permite verificar la diferencia. Supongamos que a un sujeto inteligente y honesto (del cual se puede esperar consistencia y veracidad) se le pide que dé su opinión acer-

2 En el ejemplo la autora se refiere al Partido Laborista británico, que está en favor de inversiones en el Sistema de Salud mayores que las asigna. das por el actual gobierno conservador. (Nota del autor del resumen.) 
ca de las tres proposiciones siguientes, pudiendo en cada caso escoger entre las respuestas 'Es verdadera', 'es falsa' y 'no tengo opinión'.

(4) El Partido Laborista no ganará la siguiente elección.

(5) El Partido Laborista no ganará la siguiente elección, o el Sistema Nacional de Salud será desmantelado por el siguiente gobierno.

(6) Si el Partido Laborista gana la siguiente elección, el Sistema Nacional de Salud será desmantelado por el siguiente gobierno.

Si una persona racional contesta 'es verdadera' a propósito de (4), deberá considerar que también (5) es verdadera; sin embargo, parece que puede responder, consistentemente, que (6) es falsa. El test muestra que no es el caso, pues, que un condicional cuyo antecedente es considerado muy probablemente falso, debe considerarse muy probablemente verdadero, sólo que de uso inapropiado en algunos contextos. El test muestra que un sujeto racional puede creer (4), y algunas otras proposiciones sobre el Laborismo, y en virtud de tales creencias puede ser llevado, no sólo a abstenerse de afirmar (6) sino también a creer que (6) es falso (y sólo la abstención debería registrarse si Grice estuviera en lo cierto sobre el condicional).

\section{A qué equivale afirmar que si $A, B$}

En esta sección se proporciona una explicación positiva de qué es afirmar o creer en un condicional, $y$ tal explicación echa luz sobre la conducta del sujeto al que se sometía a un test en la sección anterior. Llamemos ' $\mathrm{L}$ ' y ' $\mathrm{N}$ ' a las proposiciones siguientes:

(L) El Partido Laborista ganará la siguiente elección.

(N) El Sistema Nacional de Salud será desmantelado por el siguiente gobierno.

En el diagrama siguiente, las alturas verticales representan las probabilidades de las distintas proposiciones. Para evaluar la probabilidad de ' $\mathrm{Si} \mathrm{L}, \mathrm{N}$ ', el sujeto supone $\mathrm{L}$ e ignora lo que ocurre con las --L probabilidades. Esto lo lleva a otorgar baja probabilidad a 'Si L, N'. Pero la probabilidad de '-L $\vee N$ ' es alta, lo que imuestra nuevamente la inadecuación del análisis veritativo-funcional del condicional. 


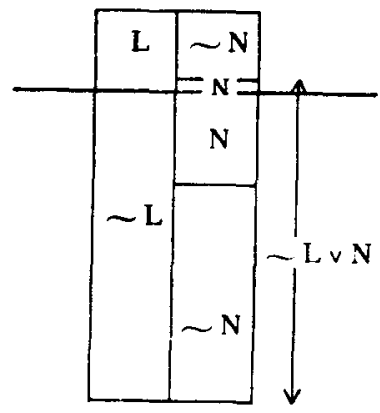

Fig. 1

Juzgar probable 'A $\supset \mathrm{B}$ ' es juzgar improbable 'A \& - B'. Juzgar probable 'Si A,B' no es sólo juzgar improbable 'A \& -B' sino también considerar que la probabilidad de 'A \& $B$ ' es menor que la de 'A \& B'. La pregunta ' $¿$ Es B probable, dado A?' es la pregunta '¿Es A \& B casi tan probable como A?'

La autora finaliza la sección con el análisis de otros ejemplos que suministran más elementos de juicio en favor de que la probabilidad de un condicional indicativo difiere de la probabilidad del condicional material a que sería equivalente según el análisis veritativo-funcional.

4. Continuación de los argumentos sobre el análisis veritativofuncional

Se refuerzan los argumentos contra el análisis veritativo-funcional, se hacen a propósito de una idea de F. Jackson consideraciones semejantes a las que se hicieron sobre la propuesta de Grice y se muestra que el análisis veritativo-funcional lleva a paradojas en la evaluación de razonamientos y en el análisis de condicionales que forman parte de otros. Todo esto refuerza la conclusión de que la creencia en un condicional y la creencia en la implicación material no coinciden.

\section{Continuación de la teoria positiva}

$\mathrm{El}$ análisis de la sección 3 conduce al siguiente criterio: $\mathrm{x}$ cree que (juzga probable que) si $A, B$, en la medida en que él juzga que A \& B es casi tan probable como $\mathrm{A}$, o, lo que es aproximadamente 
lo mismo, en la medida en que él juzga que $\mathrm{A} \& \mathrm{~B}$ es más probable que $\mathrm{A} \&$ \& $\mathrm{B}$.

Si se hace una idealización, suponiendo que los juicios de probabilidad subjetiva de un sujeto son bastante precisos como para que se les pueda asignar números entre 0 y 1 inclusive, el criterio anterior conduce a tomar la fórmula siguiente como medida del grado de confianza de un sujeto $x$ en el condicional 'Si A, B':

$$
\frac{P_{x}(A \& B)}{P_{X}(A)}
$$

La autora hace dos aclaraciones importantes sobre la fórmula. En primer lugar, la idealización que supone la fórmula (ver el párrafo anterior), no es necesaria para sus argumentos; lo que so usa en ellos es el criterio enunciado dos párrafos más atrás. En segundo lugar, aun aceptando la idealización de los valores numéricos, la fórmula no es entendida como una definición reductiva de la probabilidad subjetiva de un condicional para un sujeto, como si tal probabilidad debiera calcularse dividiendo la probabilidad que tiene la conjunción del antecedente y el consecuente por la probabilidad del antecedente. Hay ocasiones en que un sujeto tiene un grado de confianza bien definido en un condicional y sin embargo no tiene opinión sobre la probabilidad del antecedente (yo no sé cuán probable es que un compañero de trabajo arroje una moneda al suelo en los próximos días, pero creo que si lo hace, la moneda saldrá águila con un grado de confianza (probabilidad subjetiva) de 1/2).

La fórmula transcrita más arriba es conocida en la teoría de la probabilidad como la probabilidad condicional de $B$ dado $A$. La tesis positiva podría expresarse, pues, de esta manera: el grado de confianza de una persona en un condicional, si A, B, es la probabilidad condicional que tal persona asigna a $B$, dado $A$.

Mediante la aplicación de la teoría positiva a diversos ejemplos, la autora suministra más elementos de juicio en favor de la plausibilidad de tal teoría y muestra, simultáneamente, la implausibilidad del análisis veritativo-funcional.

\section{El argumento contra condiciones de verdad no veritativo-funcionales}

Si un condicional ' $\mathrm{Si} A, \mathrm{~B}$ ' tiene condiciones de verdad que no son 
veritativo-funcionales, se sigue que al menos en alguna de las cuatro combinaciones de valores de verdad de $\mathrm{A}$ y $\mathrm{B}$, la asignación de valores a A y B no implica un valor para el condicional. La autora trata de establecer su tesis mediante un "tetralema", mostrando que cualquiera que sea la combinación de valores de verdad de $\mathbf{A}$ y $\mathbf{B}$ en que "falle" la veritativo-funcionalidad, tal supuesta "falla" conduce a conclusiones incompatibles con la teoría positiva de la sección 5 ; además, toda vez que se produce el choque entre la hipótesis de condiciones de verdad no veritativo-funcionales y la teoría positiva antes mencionada, las intuiciones favorecen la segunda alternativa.

Supongamos, por ejemplo, que falla la veritativo-funcionalidad cuando A y $B$ son verdaderos. Esto significa que la verdad de $A$ y de $B$ no determina un valor de verdad de 'Si A, B'. Esto implica, a su vez, que yo puedo estar seguro de que $A$ es verdadero $y$ de que $B$ es verdadero, y sin embargo no tener opinión definida sobre el valor de ' $\mathrm{Si} \mathrm{A}, \mathrm{B}$ '. ${ }^{3}$ Esta consecuencia es incompatible con la teoría positiva antes formulada: si los valores de $P_{X}(A)$ y $P_{X}(B)$ son muy altos, el valor de $\frac{P_{X}(A \& B)}{P_{X}(A)}$ es muy alto. Se sigue una consecuencia equivalente respecto de la probabilidad subjetiva del condicional sin suponer la idealización numérica. Análisis de ejemplos del lenguaje cotidiano suministran apoyo independiente a la conclusión arrojada por la teoría de la sección 5 . Queda eliminada, pues, la posibilidad de que 'Si $\mathrm{A}, \mathrm{B}$ ' tenga condiciones de verdad no veritativo-funcionales tales que no determinen que ' $\mathrm{Si} A, B$ ' es verdadero si $\mathrm{A}$ y $\mathrm{B}$ lo son.

El supuesto de que falla la veritativo-funcionalidad cuando $A$ es verdadero y $B$ falso, se analiza de manera similar. Si se produjera tal falla, alguien podría estar seguro de la verdad de A y la falsedad de $B$ y ser agnóstico respecto del condicional. Esta consecuencia es incompatible con la teoría de la sección 5 y con intuiciones muy fuertes del lenguaje cotidiano: está claro que estar seguro de $A$ y $-B$ lleva a rechazar 'Si A, B'.

Supongamos que la veritativo-funcionalidad falla en el caso en que A es falso y B verdadero. ¿Cómo reaccionará frente a 'Si A, B', una persona $x$ que está segura de que $B$ y en duda respecto de $A$ ? De

3 Hay excepciones a la generalización de que si un conectivo binario tiene condiciones de verdad que no son veritativo-funcionales en el caso en que se aplica a componentes verdaderos, entonces se puede estar seguro de que los dos componentes son verdaderos y dudar del compuesto; pero la autora muestra que tales excepciones no afectan el análisis de los condicionales. 
acuerdo con la teoría positiva propuesta, $\mathrm{x}$ estará seguro de que $\mathrm{Si}$ A, B; nuevamente, la suposición de que falla la veritativo-funcionalidad (ahora respecto del caso $A$ falso-B verdadero), arroja un resultado incompatible con el de la teoría positiva, porque si existe tal falla, hay tres posibles alternativas para $x$, $y$ en una de ellas el condicional es falso. Las posibilidades son, en efecto:

$\begin{array}{ccc}\text { A } & \text { B } & \text { Si A, B } \\ \text { v } & \text { v } & \text { v } \\ \text { f } & \text { v } & \text { v } \\ \mathbf{f} & \text { v } & \text { f }\end{array}$

(En el análisis de la primera línea se usa la conclusión de que la veritativo-funcionalidad no puede fallar en el caso verdad-verdad, conclusión ya establecida antes.)

Supongamos, finalmente, que la veritativo-funcionalidad falla en el caso A falso-B falso. Sea $x$ una persona que está segura de que ambas proposiciones tienen el mismo valor de verdad, pero no sabe cuál es. Sus creencias bastan para arrojar seguridad en el condicional: $B$ es seguro, bajo el supuesto de que A. Nuevamente, el supuesto de que falla la veritativo-funcionalidad lleva a resultados diferentes, porque si las condiciones de verdad de 'Si A, B' no determinan un valor unívoco para el caso falsedad-falsedad, tres posibilidades, una de las cuales arroja la falsedad del condicional, están abiertas para $x$ :

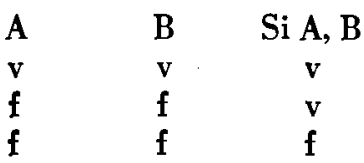

(Nuevamente se usa en el análisis la conclusión ya alcanzada respecto del caso verdadero-verdadero.)

El tetralema ha conducido a la conclusión de que ' $\mathrm{Si} A, B$ ' no puede tener condiciones de verdad no veritativo-funcionales. Pero antes se mostró que tampoco puede tener condiciones de verdad veritativo-funcionales. Luego, ' $\mathrm{Si} \mathrm{A}, \mathrm{B}$ ' no tiene condiciones de verdad.

La autora finaliza la sección mostrando en un ejemplo la capacidad explicativa de la teoría positiva propuesta. Se muestra que, si bien la inferencia -(A\&-B) / Si A, B no es válida, la teoría puede 
explicar por qué resultan intuitivamente aceptables razonamientos de esa estructura. Básicamente, se muestra que en ciertas condiciones, la creencia en un caso de - (A\&-B) es suficiente para creer en Si A, B.

7. Algunas observaciones finales

Se aclara que el argumento no depende de una concepción de lo que es la verdad. Sólo se hacen unos pocos supuestos triviales sobre el uso de la noción. También se extraen algunas consecuencias de las conclusiones alcanzadas. 